Analisis Faktor-faktor yang Berhubungan ...... (Ari Murdiati, Sutopo Patria Jati)

\title{
Analisis Faktor-Faktor Yang Berhubungan Dengan Perilaku Ibu Hamil Dalam Merencanakan Persalinan Untuk Pencegahan Komplikasi Di Wilayah Kerja Puskesmas Bandarharjo Kota Semarang
}

\author{
Ari Murdiati *), Sutopo Patria Jati **) \\ *) AKBID Abdi Husada Semarang \\ Korespondensi : \\ **) Magister Promosi Kesehatan Universitas Diponegoro Semarang
}

\begin{abstract}
ABSTRAK
Data kematian maternal yang diperoleh dari Dinas Kesehatan Kota Semarang tahun 2012 menunjukkan bahwa Puskemas Bandarharjo menempati urutan teratas sepanjang tahun 2009-2012. Salah satu upaya terobosan untuk percepatan penurunan AKI adalah Program Perencanaan Persalinan dan Pencegahan Komplikasi (P4K) dengan stiker. Penelitian ini merupakan penelitian kuantitatif, jenis penelitian explanatory research, dengan rancangan cross sectional. Hasil penelitian menunjukkan ibu hamil yang memiliki perencanaan persalinan tidak baik sebanyak 62,2\%, sedangkan ibu hamil yang memiliki perencanaan persalinan baik hanya 37,8\%. Enam variabel yang berhubungan secara statistik signifikan yaitu paritas, pengetahuan ibu hamil, sikap ibu hamil, ketersediaan sarana dan prasarana, dukungan suami, dan dukungan petugas kesehatan. Variabel yang paling dominan berpengaruh adalah dukungan suami $(O R=7,037)$. Hal ini berarti bahwa dukungan suami dalam program perencanaan persalinan yang baik memungkinkan ibu hamil memiliki perencanaan persalinan yang baik 7,037 kali dibanding dengan dukungan suami yang kurang.
\end{abstract}

Kata Kunci : Perilaku, Ibu hamil, P4K

\begin{abstract}
Analysis of Factors Related to the Behavior of Pregnant Women in Planning Labor for Prevention of Complications in the Working Area of Puskesmas Bandarharjo Kota Semarang. Maternal mortality data from Semarang City Health Office in 2012 showed that Puskesmas Bandarharjo was the top ranks throughout 2009-2012. One ground breaking effort to accelerate the decline of AKI is Childbirth Program Planning and Prevention Complications (P4K) with stickers. This study is a quantitative study with explanatory research, with a design using cross-sectional study. the results of the univariate analysis suggests that pregnant women who have a good labor planning as much as 37,8\%. While the pregnant women, who have a birth plan not good is only is. The results of bivariate analysis using the statistical test Chi-Square shows there are six variables significantly associated: parity, maternal knowledge, maternal attitudes, availability of facilities and infrastructure, husband support, and support for health workers. The most dominant variable is the support of the husband (OR =7,037). This means that the support of her husband in a good birth planning program allows pregnant women has good labor planning 7,037 times compared with less support husband.
\end{abstract}

Keywords: Behavior, Pregnancy, $P 4 K$ 


\section{PENDAHULUAN}

Angka Kematian Ibu (AKI) di Indonesia saat ini masih tergolong tinggi untuk negaranegara ASEAN. Menurut Survei Demografi Kesehatan Indonesia (SDKI) tahun 2007, AKI di Indonesia sebesar 228/100.000 kelahiran hidup. Padahal pemerintah telah bertekad akan menurunkan AKI di tahun 2010 sebesar 150/100.000 kelahiran hidup, dan target AKI di tahun 2015 sebesar 102/100.000 KH (Dinkes Jateng, 2008). Tingginya AKI menunjukkan keadaan sosial ekonomi yang rendah dan penggunaan fasilitas pelayanan kesehatan termasuk pelayanan prenatal dan obstetri yang rendah pula (Kemenkes RI, 2010).

AKI di Provinsi Jawa Tengah untuk tahun 2010 berdasarkan laporan dari Kabupaten/Kota sebesar 104,97/100.000 kelahiran hidup. Angka ini telah memenuhi target dalam indikator Indonesia Sehat tahun 2010 sebesar 150/100.000 kelahiran hidup (Dinkes Jateng, 2008). AKI di Provinsi Jawa Tengah untuk tahun 2011 berdasarkan laporan dari Kabupaten/Kota sebesar 116,01/100.000 kelahiran hidup, mengalami peningkatan bila dibandingkan dengan AKI pada tahun 2010 (Dinkes Jateng, 2011).

Sebagian besar kematian ibu disebabkan oleh penyebab langsung, yaitu perdarahan, infeksi, eklampsia, persalinan lama dan abortus komplikasi. Di samping itu, kematian ibu juga dilatarbelakangi oleh rendahnya tingkat sosial ekonomi, tingkat pendidikan, kedudukan dan peran perempuan, faktor sosial budaya serta faktor transportasi, yang kesemuanya berpengaruh pada munculnya dua keadaan yang tidak menguntungkan, yaitu: (1) Tiga terlambat (terlambat mengenal tanda bahaya dan mengambil keputusan, terlambat mencapai fasilitas kesehatan dan terlambat mendapatkan pelayanan di fasilitas kesehatan); (2) Empat terlalu (terlalu muda melahirkan, terlalu sering melahirkan, terlalu rapat melahirkan, dan terlalu tua untuk melahirkan). Mengingat penyebab dan latar belakang kematian ibu yang sangat kompleks dan menyangkut bidang-bidang yang ditangani oleh banyak faktor, baik di lingkungan pemerintah maupun swasta, maka upaya percepatan penurunan AKI memerlukan penanganan yang menyeluruh terhadap masalah yang ada dengan melibatkan sektor terkait (Depkes RI, 2009).

Salah satu upaya terobosan untuk percepatan penurunan AKI adalah P4K dengan stiker. Kegiatan P4K dengan stiker juga merupakan salah satu instrumen yang efektif dalam mencapai sasaran MDGs terutama dalam hal penurunan AKI, yang terintegrasi sebagai satu kegiatan Desa Siaga (Dinkes NTB, 2008). Departemen Kesehatan 
telah membuat kebijakan tersebut melalui Keputusan Menteri Kesehatan Republik Indonesia Nomor: 741/Menkes/Per/VII/2008 tentang dikembangkannya $\mathrm{P} 4 \mathrm{~K}$ dengan penempelan stiker. Program P4K yang diharapkan bisa membangun potensi masyarakat, khususnya dalam persiapan penyelamatan ibu dan bayi baru lahir (Kemenkes RI, 2010).

Kegiatan P4K meliputi yang pertama adalah pencatatan data kehamilan yang ada di setiap tempat dengan menempelkan stiker P4K di setiap rumah ibu hamil, agar ibu hamil yang bersangkutan kondisinya dapat terpantau oleh masyarakat dan bidan. Kegiatan kedua adalah dengan membentuk kelompok donor darah agar ada jaminan ketersediaan darah yang dapat digunakan sewaktu-waktu apabila terjadi perdarahan pada ibu hamil, bersalin dan nifas. Ketiga, merencanakan atau menyiapkan sistem transportasi. Keempat, ialah perencanaan masalah pembiayaan dan menginformasikan ketersediaan bantuan dana apabila dibutuhkan (Depkes RI, 2009).

Tetapi perkembangan program belum mendapat respon yang optimal dari masyarakat terkait dengan belum terpenuhinya seluruh target penempelan stiker ataupun dilepasnya stiker yang telah tertempel oleh ibu hamil itu sendiri, hal ini jika dikaitkan dari segi provider kesehatan akan berpengaruh pada daya ungkitnya sebagai salah satu media program percepatan penurunan AKI (Kemenkes RI, 2010).

\section{METODE}

Jenis Penelitian yang digunakan adalah explanatory research dengan mengggunakan desain cross sectional atau studi belah lintang, yaitu suatu penelitian dimana variabel-variabel penelitian diukur atau dikumpulkan dalam satu waktu yang sama (Siregar, 2012). Teknik pengambilan data dengan wawancara menggunakan kuesioner yang telah disiapkan. Tempat penelitian adalah di wilayah kerja Puskesmas Bandarharjo Kota Semarang. Variabel dependent dalam penelitian ini adalah perencanaan persalinan untuk pencegahan komplikasi. Sedangkan variabel independent adalah : karakteristik responden (yang terdiri dari : umur, pendidikan, paritas, pekerjaan, dan pendapatan), pengetahuan ibu hamil tentang P4K, sikap ibu hamil terhadap P4K, ketersediaan sarana dan prasarana, dukungan suami, dan dukungan petugas kesehatan.

Populasi dalam penelitian ini adalah para ibu hamil trimester I yang berdomisili di wilayah kerja Puskesmas Bandarharjo Kota Semarang pada bulan Januari 2014 dan tercatat dalam kohort ibu di Puskesmas, 
sejumlah 90 orang. Sampel dalam penelitian ini adalah ibu hamil trimester I yang berdomisili di wilayah kerja Puskesmas Bandarharjo, yang bertempat tinggal di kelurahan Bandarharjo, Tanjung Mas, Kuningan dan Dadapsari.

\section{HASIL DAN PEMBAHASAN}

Hasil penelitian menunjukkan bahwa persentase perilaku ibu hamil dalam perencanaan persalinan untuk pencegahan komplikasi di wilayah Puskesmas Bandarharjo Kota Semarang yang tidak baik, adalah lebih besar dibandingkan perilaku ibu hamil dalam perencanaan persalinan untuk pencegahan komplikasi yang baik. Dimana sebanyak $62,2 \%$ ibu hamil memiliki perilaku perencanaan persalinan untuk pencegahan komplikasi tidak baik, dan hanya 37,8\% ibu hamil yang memiliki perencanaan persalinan untuk pencegahan komplikasi baik. Dimana hasil dari penelitian menunjukkan bahwa sebanyak 57,80\% ibu hamil tidak memiliki surat pernyataan kesediaan sarana transportasi, sebanyak $62,20 \%$ ibu hamil tidak memiliki surat pernyataan kesediaan menjadi pendonor darah, sebanyak $24,4 \% \mathrm{ibu}$ hamil tidak menempelkan stiker di depan rumah, dan sebanyak 18,90\% ibu hamil memiliki stiker $\mathrm{P} 4 \mathrm{~K}$ yang tidak diisi dengan lengkap.
Peneliti dapat mengambil kesimpulan bahwa kurangnya pengetahuan ibu hamil tentang pentingnya alat transportasi dan pentingnya donor darah (sebagai bagian dari perencanaan persalinan untuk pencegahan komplikasi), kemudian berimbas pada tingginya persentase sikap ibu hamil yang kurang baik, dan akhirnya menjadi penyebab tingginya persentase ibu hamil yang memiliki perilaku tidak baik dengan tidak memiliki surat pernyataan kesediaan sarana transportasi dan tidak memiliki surat pernyataan kesediaan menjadi pendonor darah. Dimana kondisi ini sesuai dengan teori yang disebutkan oleh Green tahun 2000, yaitu bahwa faktor predisposing yang berpengaruh secara langsung terhadap perilaku adalah pengetahuan, keyakinan, nilai, sikap dan kepercayaan (Green, 2000).

Penyebab lain dari tidak baiknya perencanaan persalinan untuk pencegahan komplikasi ibu hamil ini, kemungkinan disebabkan oleh kurangnya dukungan dari suami, sebagaimana hasil dari distribusi frekuensi jawaban mengenai dukungan suami yang menunjukkan ada sebanyak 31,11\% suami yang tidak berperan mencarikan calon pendonor darah apabila dibutuhkan sewaktuwaktu. Selain itu, faktor lain yang berpengaruh adalah kurangnya dukungan dari tenaga kesehatan, dalam hal ini 
khususnya peran para bidan puskesmas. Para bidan kemungkinan tidak aktif turun ke lapangan dalam rangka monitoring dan evaluasi terhadap pelaksanaan P4K. Hal ini cukup beralasan karena berdasarkan hasil wawancara pendahuluan dari beberapa bidan pada tanggal 18 Januari 2014, bahwa setiap pemeriksaan kehamilan yang pertama kali, ibu hamil selalu diberikan buku KMS dan stiker P4K. Namun mengenai kelengkapan pengisian stiker bidan tidak tahu karena selama ini tidak ada evaluasi mengenai kelengkapan pengisian stiker.

Dalam upaya percepatan penurunan AKI menuju tercapainya target MDGs 2015, Departemen Kesehatan telah mencanangkan P4K dengan stiker. Dimana tujuan akhir dari pelaksanaan program ini, selain akan menurunkan AKI, juga akan menurunkan Angka Kematian Bayi Baru Lahir. Karena melalui pelaksanaan $\mathrm{P} 4 \mathrm{~K}$ dengan stiker, kondisi ibu hamil akan dapat terpantau secara intensif, sehingga dapat menjalani persalinan dengan aman dan selamat serta melahirkan bayi yang sehat. Disamping itu, melalui P4K, ibu hamil, suami, keluarga dan masyarakat diberdayakan melalui peningkatan pengetahuan tentang kehamilan, tanda bahaya dan komplikasinya serta pentingnya persalinan termasuk pemilihan metode kontrasepsi yang akan digunakan. Dengan kata lain, dalam P4K masyarakat memegang peranan penting dalam upaya penyelamatan ibu dan bayi baru lahir (Dinkes Jateng, 2011). Maka, pelaksanaan program P4K yang tidak baik akan berpengaruh terhadap kematian ibu dan bayi, sebagaimana data yang diperoleh dari Dinas Kesehatan Kota Semarang tahun 2012, yang menunjukkan bahwa kematian maternal di Puskemas Bandarharjo menempati urutan teratas sepanjang tahun 2009 sampai tahun 2012 (Dinkes Kota Semarang, 2012).

Berdasarkan hasil dari penelitian ini, dapat diketahui bahwa faktor-faktor yang berpengaruh secara bersama-sama terhadap perilaku ibu hamil dalam perencanaan persalinan untuk pencegahan komplikasi, adalah : 1) Dukungan suami dalam perencanaan persalinan untuk pencegahan komplikasi dengan nilai $\mathrm{OR}=7,037 ; 2$ ) Sikap ibu hamil tentang perencanaan persalinan untuk pencegahan komplikasi dengan nilai $\mathrm{OR}=6,637 ; 3$ ) dukungan petugas kesehatan dalam perencanaan persalinan untuk pencegahan komplikasi dengan nilai $\mathrm{OR}=5,962 ; 4)$ Pengetahuan tentang perencanaan persalinan untuk pencegahan komplikasi dengan nilai $\mathrm{OR}=$ 4,497 . 


\section{Umur}

Umur adalah lama hidup individu terhitung mulai saat lahir sampai saat dilakukan penelitian. Semakin cukup umur, tingkat kematangan seseorang akan lebih matang dalam berfikir dan bekerja (Notoatmodjo, 2003). Bila umur kehamilan dikaitkan dengan risiko komplikasi kehamilan, maka kehamilan yang berisiko adalah kehamilan usia kurang dari 20 tahun dan kehamilan di atas 35 tahun. Sedangkan usia kehamilan yang tidak berisiko yaitu usia kehamilan antara 20-35 tahun.

Hasil analisis univariat menunjukkan bahwa sebanyak $61,1 \%$ ibu hamil berada pada usia kehamilan yang tidak berisiko. Hasil analisis bivariat menunjukkan tidak ada hubungan antara umur ibu hamil dengan perilaku ibu hamil dalam perencanaan persalinan untuk pencegahan komplikasi ( $p$ value : 0,310>0,05).

Sebagaimana yang diungkapkan oleh Green tahun 2000 bahwa umur merupakan faktor demografi yang tidak berpengaruh secara langsung terhadap perilaku, dan bahwa faktor yang berpengaruh secara langsung terhadap perilaku adalah faktor predisposing (pengetahuan, keyakinan, nilai, sikap dan kepercayaan), faktor pemungkin (ketersediaan sarana kesehatan, hukum pemerintah atau masyarakat, dan lain-lain), faktor penguat (dukungan keluarga, dukungan teman sebaya, dukungan guru, dukungan tokoh agama, dukungan pengambil kebijakan, dan lain-lain) (Green, 2000).

Tidak adanya hubungan antara umur ibu hamil dengan perilaku Ibu hamil dalam perencanaan persalinan untuk pencegahan komplikasi kehamilan kemungkinan disebabkan karena kesempatan untuk mencari atau memperoleh informasi tentang perencanaan persalinan untuk pencegahan komplikasi kehamilan adalah sama antara ibu yang hamil pada usia yang berisiko dengan ibu yang hamil pada usia tidak berisiko. Hal ini dikarenakan responden berada di wilayah perkotaan dan menempati tempat tinggal saling berdekatan.

\section{Pendidikan}

Tingkat pendidikan adalah jenjang pendidikan formal tertinggi yang pernah diikuti responden. Kategori pendidikan dalam penelitian ini dibagi menjadi dua kategori yaitu pendidikan dasar ( $\leq 9$ tahun) dan pendidikan menengah (> 9 tahun). Hasil analisis univariat menunjukkan bahwa sebanyak $55,6 \%$ ibu hamil berpendidikan menengah. Hasil analisis bivariat menunjukkan tidak ada hubungan antara pendidikan ibu hamil dengan perilaku ibu hamil dalam perencanaan persalinan untuk 
pencegahan komplikasi (p-value: 1,000 > $0,05)$.

Hasil penelitian ini bertolak belakang dengan apa yang dikatakan oleh Notoatmodjo, yaitu bahwa tingkat pendidikan seseorang akan berpengaruh dalam memberikan respon terhadap sesuatu yang datang dari luar. Orang yang berpendidikan tinggi akan memberikan respon yang lebih rasional terhadap informasi yang datang dan akan berpikir sejauh mana keuntungan yang mungkin diperoleh dari gagasan tersebut (Notoatmodjo, 2003).

Menurut Green ada tiga faktor yang berpengaruh secara langsung terhadap perubahan perilaku yaitu : 1) faktor predisposing yang meliputi pengetahuan, sikap, keyakinan, nilai dan persepsi, 2) faktor reinforcing yang meliputi sikap dan perilaku orang lain di luar diri pribadi, 3) faktor enabling yang meliputi ketersediaan sumber daya, keterjangkauan akses, aturan atau kebijakan, keahlian, dan lain-lain (Green, 2000). Maknanya menurut teori perilaku Green, pendidikan bukan merupakan faktor yang berpengaruh secara langsung terhadap perubahan perilaku.

Tidak adanya hubungan antara pendidikan ibu hamil dengan perilaku ibu hamil dalam perencanaan persalinan untuk pencegahan komplikasi kehamilan ini didukung oleh teori perilaku yang menyatakan bahwa hasil pendidikan adalah perubahan kemampuan pelakunya, selanjutnya perubahan perilaku didasari adanya perubahan atau penambahan pengetahuan, sikap atau keterampilannya. Tetapi perubahan pengetahuan dan sikap bukan merupakan jaminan perubahan perilaku sebab perilaku tersebut kadangkadang memerlukan material (Jalaluddin, 2012).

\section{Pekerjaan}

Kategori pekerjaan dalam penelitian ini dibagi menjadi dua kategori yaitu bekerja dan tidak bekerja. Adapun hasil analisis univariat menunjukkan bahwa sebanyak $60 \%$ ibu hamil adalah bekerja. Hasil analisis bivariat menunjukkan tidak ada hubungan antara pekerjaan ibu hamil dengan perilaku ibu hamil dalam perencanaan persalinan untuk pencegahan komplikasi kehamilan ( $p$ value: $0,399>0,05)$.

Menurut Green tahun 2000 ada tiga faktor yang berpengaruh secara langsung terhadap perubahan perilaku yaitu 1) faktor predisposing yang meliputi pengetahuan, sikap, keyakinan, nilai dan persepsi, 2) faktor reinforcing yang meliputi sikap dan perilaku orang lain di luar diri pribadi, 3) faktor enabling yang meliputi ketersediaan sumber daya, keterjangkauan akses, aturan atau 
kebijakan, keahlian, dan lain-lain (Green, keluarga, dukungan teman sebaya, dukungan 2000). Maknanya menurut teori perilaku guru, dukungan tokoh agama, dukungan

Green, pekerjaan bukan merupakan faktor yang berpengaruh secara langsung terhadap perubahan perilaku.

\section{Pendapatan}

Tingkat pendapatan dapat menunjukkan status sosial ekonomi suatu keluarga. Pendapatan responden dibedakan menjadi dua kategori yaitu di bawah standar UMR (< Rp 1.209.100) dan di atas standar UMR ( $\geq$ Rp 1.209.100). Hasil analisis univariat menunjukkan bahwa sebanyak $56,7 \%$ ibu hamil memiliki pendapatan di atas standar UMR. Hasil analisis bivariat menunjukkan ada hubungan antara pendapatan ibu hamil dengan perilaku ibu hamil dalam perencanaan persalinan untuk pencegahan komplikasi ( $p$-value: 0,002 >0,05).

Sebagaimana yang diungkapkan oleh Green tahun 2000 bahwa penghasilan merupakan faktor demografi yang tidak berpengaruh secara langsung terhadap perilaku. Akan tetapi faktor yang berpengaruh secara langsung terhadap perilaku yaitu faktor predisposing yang meliputi pengetahuan, keyakinan, nilai, sikap dan kepercayaan. Faktor pemungkin yang meliputi ketersediaan sarana kesehatan, hukum pemerintah atau masyarakat, dan lainlain. Faktor penguat yang meliputi dukungan pengambil kebijakan, dan lain-lain (Green, 2000).

\section{Paritas}

Paritas merupakan Jumlah anak yang telah dilahirkan oleh seorang ibu baik lahir hidup maupun mati. Dimana pengkategorian paritas dalam penelitian ini dibedakan menjadi dua kategori yaitu belum pernah melahirkan dan pernah melahirkan. Hasil analisis univariat menunjukkan bahwa sebanyak 56,7\% ibu hamil pernah melahirkan. Hasil analisis bivariat menunjukkan ada hubungan antara paritas ibu hamil dengan perilaku ibu hamil dalam perencanaan persalinan untuk pencegahan komplikasi ( $p$-value: $0,011<0,05)$.

Paritas kaitannya dengan perilaku ibu hamil dalam perencanaan persalinan untuk pencegahan komplikasi kehamilan tidak terlepas dari apa yang disebut dengan pengalaman. Untuk memperoleh pengalaman ada empat cara tradisional yang digunakan. Pertama adalah cara coba-salah (trial and error), cara ini dilakukan dengan mencobacoba, jika gagal akan diulang-ulang hingga berhasil. Kedua adalah cara kekuasaan atau otoritas, pada cara ini pengetahuan didapatkan dari orang yang berpengaruh dalam masyarakat lalu diikuti tanpa 
rasionalisasi. Ketiga adalah berdasarkan pengalaman pribadi, dimana pengalaman seseorang akan memberi pengetahuan baru pada orang tersebut. Keempat adalah melalui jalan pikiran, maksudnya pengetahuan diperoleh seseorang dengan penalaran dan membuat kesimpulan (Notoatmodjo, 2010).

Berkaitan dengan hal tersebut, peneliti berpendapat bahwa ibu hamil yang sudah pernah hamil dan berpengalaman dalam melahirkan, apalagi pernah mengalami masalah dalam kehamilannya, maka biasanya sampai melahirkan ibu tersebut akan lebih menjaga terhadap kesehatannya, khususnya dalam hal menjaga kehamilannya agar tetap sehat. Kondisi berbeda akan terjadi pada ibu yang belum pernah melahirkan, dimana biasanya mereka bingung tentang apa yang harus dilakukan berkaitan dengan kehamilannya. Sehingga akhirnya akan ada perbedaan pada perilaku perencanaan persalinan untuk pencegahan komplikasi berdasarkan paritasnya.

\section{Pengetahuan}

Tingkat pengetahuan ibu hamil tentang perencanaan persalinan untuk pencegahan komplikasi kehamilan adalah kemampuan responden untuk mengetahui dan memahami tentang perencanaan persalinan untuk pencegahan komplikasi kehamilan, meliputi persiapan persalinan yang aman, tanda bahaya kebidanan, persiapan menghadapi komplikasi, pemakaian metode KB pasca persalinan. Adapun pengkategorian pengetahuan dalam penelitian ini dibagi menjadi dua kategori yaitu pengetahuan baik dan pengetahuan kurang.

Hasil analisis univariat menunjukkan bahwa sebanyak $64,4 \%$ memiliki pengetahuan yang baik tentang perencanaan persalinan. Hasil analisis bivariat menunjukkan ada hubungan antara pengetahuan ibu hamil tentang perencanaan persalinan untuk pencegahan komplikasi dengan perilaku perencanaan persalinan untuk pencegahan komplikasi ( $p$-value: 0,000 $<0,05)$.

Adanya hubungan antara pengetahuan ibu hamil tentang perencanaan persalinan untuk pencegahan komplikasi dengan perilaku ibu hamil dalam perencanaan persalinan untuk pencegahan komplikasi ini didukung oleh teori Lawrence Green dalam buku Notoatmodjo, yang menyebutkan bahwa peningkatan pengetahuan tidak selalu menyebabkan perubahan perilaku, tetapi pengetahuan merupakan faktor penting dalam perubahan perilaku. Perilaku dan tindakan dapat dipengaruhi oleh beberapa faktor, salah satunya adalah pengetahuan. Pengetahuan merupakan domain yang sangat penting dalam membentuk perilaku 
seseorang. Pengetahuan diperlukan sebagai dorongan berfikir dalam menumbuhkan kepercayaan diri maupun dorongan sikap dan perilaku, sehingga dapat dikatakan bahwa pengetahuan merupakan stimuli terhadap tindakan seseorang. Disamping itu, perilaku yang dalam pembentukannya didasari oleh pengetahuan akan bersifat lebih langgeng (Notoatmodjo, 2003).

\section{Sikap}

Sikap adalah kesiapan merespon yang sifatnya positif atau negatif terhadap objek atau situasi secara konsisten (Ahmadi, 2002). Hasil analisis univariat menunjukkan bahwa sebanyak $60 \%$ ibu hamil memiliki sikap yang baik tentang perencanaan persalinan untuk pencegahan komplikasi. Hasil analisis bivariat menunjukkan ada hubungan antara sikap ibu hamil tentang perencanaan persalinan untuk pencegahan komplikasi dengan perilaku ibu hamil dalam perencanaan persalinan untuk pencegahan komplikasi ( $p$-value: 0,002<0,05).

Adanya hubungan antara sikap ibu hamil tentang perencanaan persalinan untuk pencegahan komplikasi dengan perilaku ibu hamil dalam perencanaan persalinan ini didukung oleh teori Green tahun 2000, yaitu bahwa sikap merupakan predisposing faktor yang akan berpengaruh terhadap motivasi seseorang atau sekelompok orang untuk melakukan suatu tindakan. Sikap tersebut masuk dalam area psikologis seseorang dimana sikap merupakan respon dari seseorang, baik itu berupa respon positif atau respon negatif, yang nantinya bisa jadi akan dikeluarkan dalam bentuk tindakan nyata (Notoatmodjo, 2003).

Sikap menggambarkan suka atau tidak suka seseorang terhadap objek. Sikap sering diperoleh dari pengalaman sendiri atau dari orang lain yang paling dekat. Hal ini sejalan dengan apa yang dikemukakan oleh Azwar tahun 1995, bahwa sikap yang diperoleh dari pengalaman akan menimbulkan pengaruh langsung terhadap perilaku berikutnya. Sarwono tahun 1993 juga menyatakan bahwa sikap seseorang dapat berubah dengan diperolehnya tambahan informasi tentang objek tersebut, melalui persuasi serta tekanan dari kelompok sosialnya (Kholid, 2012).

Mengacu pada teori-teori tentang sikap tersebut, maka peneliti dapat menyimpulkan bahwa semakin baik sikap ibu hamil tentang perencanaan persalinan, maka akan semakin baik pula perilaku ibu hamil dalam perencanaan persalinan. Hal ini juga didukung oleh hasil analisis bivariat menggunakan chi square yang menunjukkan bahwa persentase ibu hamil yang memiliki perencanaan persalinan yang baik, lebih besar pada ibu hamil yang memiliki sikap 
baik yaitu sebesar $51,9 \%$, dibanding ibu hamil yang memiliki sikap kurang yaitu sebesar $16,7 \%$.

\section{Ketersediaan Sarana dan Prasarana}

Hasil analisis univariat menunjukkan bahwa sebanyak $61,1 \%$ memiliki ketersediaan sarana dan parasarana yang baik dalam perencanaan persalinan. Hasil analisis bivariat menunjukkan bahwa ada hubungan antara ketersediaan sarana dan prasarana ibu hamil dalam perencanaan persalinan dengan perilaku ibu hamil dalam perencanaan persalinan ( $p$-value: $0,035<0,05)$.

Green tahun 2000 menyatakan bahwa yang termasuk dalam faktor pemungkin yaitu ketersediaan sarana kesehatan, ketersediaan sarana transportasi akan berdampak pada respon masyarakat untuk berpartisipasi dalam program-program kesehatan. Disamping faktor pemungkin lainnya, seperti keahlian seseorang, organisasi atau masyarakat akan mengakibatkan terjadinya perubahan perilaku dan lingkungan (Green, 2000).

Berdasarkan hasil distribusi frekuensi jawaban ketersediaan sarana dan prasarana, serta hasil distribusi frekuensi jawaban pengetahuan, maka peneliti dapat mengambil kesimpulan bahwa lebih dari $90 \%$ responden tahu rumah sakit merupakan tempat yang tepat untuk proses persalinan, dan lebih dari
$90 \%$ responden tahu bahwa bidan merupakan tenaga yang kompeten untuk membantu proses persalinan, tetapi keterbatasan sarana dan prasarana menjadi faktor penghambat terlaksananya $\mathrm{P} 4 \mathrm{~K}$, yaitu ketika ibu hamil tidak bisa mendapatkan kendaraan roda empat untuk membantu menuju tempat persalinan, atau ketika kendaraan roda empat tersedia tapi tidak bisa sampai ke tempat persalinan, maka pelaksanaan $\mathrm{P} 4 \mathrm{~K}$ akan mengalami hambatan dan menjadikannya kurang terlaksana dengan baik. Oleh karena itu, ketika semakin baik ketersediaan sarana dan prasarana yang menunjang pelaksanaan P4K, akan semakin baik pula pelaksanaan program tersebut. Begitu juga sebaliknya ketika ketersediaan sarana dan prasarana yang menunjang pelaksanaan $\mathrm{P} 4 \mathrm{~K}$ kurang baik, maka akan kurang baik pula pelaksanaan program tersebut.

\section{Dukungan Suami}

Dukungan suami merupakan tanggapan responden terhadap pertanyaan yang berhubungan dengan tindakan-tindakan yang dilakukan oleh suami yang berhubungan dengan segala bentuk bantuan yang diberikan suami kepada istri untuk kehamilannya, bantuan meliputi: dukungan informatif, dukungan emosional, dukungan instrumental, maupun dukungan penilaian suami. Kategori dukungan suami dalam penelitian ini 
dikategorikan menjadi dua kategori yaitu mendukung dan kurang mendukung. Adapun hasil analisis univariat menunjukkan bahwa sebanyak $63,3 \%$ mendukung dalam perencanaan persalinan. Hasil analisis bivariat menunjukkan ada hubungan antara dukungan suami dalam perencanaan persalinan dengan perilaku ibu hamil dalam P4K (p-value : $0,000<0,005)$.

Dalam kamus besar Bahasa Indonesia dukungan adalah suatu bentuk dari bantuan yang diberikan seseorang kepada orang lain. Dukungan sosial dianggap dapat melemahkan dampak stress, dan secara langsung memberikan kesehatan mental individu dan keluarga (Setiadi, 2008). Dukungan sosial keluarga mengacu pada dukungan sosial yang dipandang oleh anggota keluarga sebagi sesuatu yang dapat diadakan atau diperlukan keluarga. Suami merupakan bagian dari keluarga, maka dukungan suami sangat diperlukan. Dukungan suami merupakan dorongan terhadap ibu hamil, baik secara moral maupun material, dimana dukungan suami sangat mempengaruhi ibu dalam menghadapi kehamilan dan persalinan (Nolan, 2003).

Norma sosial keluarga responden, dorongan anggota keluarga, termasuk kawan terdekat untuk mempengaruhi agar seseorang dapat menerima sesuatu yang dianggap baik dalam menghadapi problema kesehatan, sering diyakini kebenarannya dan kemudian diikuti. Saran, nasehat, dan motivasi anggota keluarga ataupun kawan dapat mempengaruhi perilaku (Green, 2000).

Mengingat pentingnya dukungan suami seperti apa yang telah disebutkan dalam teori-teori di atas, dan menyadari adanya beberapa dukungan suami yang dirasakan kurang, maka peneliti dapat menyimpulkan beberapa hal, yaitu berkaitan dengan tingginya persentase suami tidak menemani istri ketika melakukan pemeriksaan kehamilan kemungkinan disebabkan oleh pekerjaan masing-masing yang mungkin menyebabkan mereka jarang bertemu; berkaitan dengan tidak adanya uang yang ditabung untuk mempersiapkan diri ketika melahirkan kemungkinan disebabkan oleh uang yang diperoleh hanya cukup untuk memenuhi kebutuhan sehari-hari; dan berkaitan dengan kurangnya dukungan suami untuk hal yang lain, kemungkinan besar memang karena kurangnya informasi yang dimiliki oleh suami maupun keluarga. Maka mengingat hal ini, perlu ada peran serta dari masyarakat maupun petugas kesehatan untuk selalu memberikan berbagai informasi tentang kehamilan, persalinan dan pasca persalinan kepada ibu hamil dan keluarganya. 


\section{Dukungan Petugas Kesehatan}

Dukungan petugas kesehatan adalah tanggapan responden terhadap pertanyaan yang berhubungan dengan tindakan-tindakan yang dilakukan oleh tenaga kesehatan terdekat yang berhubungan dengan perencanaan persalinan untuk pencegahan komplikasi, meliputi: dukungan informatif, dukungan emosional, dukungan instrumental, maupun dukungan penilaian. Dimana dukungan petugas kesehatan dalam penelitian ini dibagi menjadi dua kategori yaitu mendukung dan kurang mendukung.

Adapun hasil analisis univariat menunjukkan bahwa sebanyak 68,9\%, petugas kesehatan mendukung pelaksanaan P4K. Hasil analisis bivariat menunjukkan ada hubungan antara dukungan petugas kesehatan dalam perencanaan persalinan dengan perilaku ibu hamil dalam perencanaan persalinan ( $p$-value: $0,004<$ $0,05)$.

Green tahun 2000 menyatakan bahwa faktor yang menentukan terjadinya perubahan perilaku adalah faktor reinforcing atau faktor penguat. Dimana yang termasuk dalam faktor tersebut salah satunya adalah dukungan tenaga kesehatan. Dukungan tenaga kesehatan dalam melakukan suatu tindakan akan memperkuat terjadinya seseorang untuk melakukan sebagaimana yang diinginkan oleh petugas kesehatan. Terjadinya perubahan perilaku tersebut juga bisa terjadi karena adanya dukungan masyarakat, dukungan praktisi promosi kesehatan dan pendidik kesehatan (Green, 2000).

Berkaitan dengan hasil penelitian tentang dukungan tenaga kesehatan yang dikaitkan dengan apa yang seharusnya dilakukan oleh tenaga kesehatan. Maka peneliti dapat menyimpulkan bahwa kemungkinan tenaga kesehatan tidak melakukan KIE secara maksimal kepada masyarakat khususnya kepada ibu hamil. Hal ini didukung oleh hasil distribusi jawaban responden menurut item jawaban tentang dukungan petugas kesehatan, dimana sebanyak 32,20\% petugas kesehatan tidak memberi nasehat menyiapkan tabungan untuk biaya persalinan, sebanyak 33,30\% petugas kesehatan yang tidak memberi saran agar suami dan keluarga menyiapkan kendaraan jika sewaktu- waktu diperlukan, dan sebanyak $25,60 \%$ petugas kesehatan tidak memberikan informasi yang lengkap, jelas dan mudah dipahami tentang rencana Keluarga Berencana yang akan diikuti setelah melahirkan. 
Faktor Yang Paling Dominan Dukungan suami merupakan dorongan

\section{Berpengaruh}

Jika dilihat dari hasil analisis univariat, maka persentase suami yang kurang mendukung istri dalam perencanaan persalinan masih cukup tinggi yaitu $36,7 \%$. Padahal dukungan suami dalam P4K merupakan faktor yang paling dominan berpengaruh terhadap perilaku ibu hamil dalam $\mathrm{P} 4 \mathrm{~K}$ dengan nilai $\mathrm{OR}=7,037$. Hal ini berarti bahwa dukungan suami dalam program perencanaan persalinan yang baik memungkinkan ibu hamil memiliki perencanaan persalinan yang baik 7,037 kali dibanding dengan dukungan suami yang kurang.

Suami siaga adalah suami yang dalam masa kehamilan sampai persalinan istrinya selalu berperan aktif dalam meningkatkan kesiapan ibu hamil dalam menghadapi persalinan. Dalam menghadapi persalinan suami memiliki peran serta yang besar, seperti menentukan persalinan ditolong oleh bidan atau dokter, menabung biaya persalinan, menanyakan kepada bidan/dokter mengenai perkiraan tanggal persalinan, meminta penjelasan tentang inisiasi menyusui dini dan ASI eksklusif, menyiapkan kendaraan jika sewaktu-waktu ibu dan bayi perlu segera ke rumah sakit (Nolan, 2003). terhadap ibu hamil, baik secara moral maupun material, dimana dukungan suami sangat mempengaruhi ibu dalam menghadapi kehamilan dan persalinan. Informasi tentang kehamilan yang didapatkan oleh suami, baik yang diperoleh dari televisi, majalah, koran maupun buku, dapat mempengaruhi pemberian dukungan suami. Secara finansial suami akan menyediakan dana atau uang untuk keperluan kehamilan, untuk pemeriksaan kehamilan, suplemen bagi ibu hamil maupun persiapan kelahiran bayi. Secara emosional, suami akan selalu mengingatkan atau memberikan saran pada ibu hamil untuk selalu perhatian dan menjaga kondisi janin. Suami juga akan mendampingi ibu dalam melakukan pemeriksaan kehamilan, meskipun tidak selalu dapat mendampingi (Nolan, 2003).

Dukungan suami dalam menghadapi kehamilan maupun persalinan sangatlah berarti, dimana suami dapat menumbuhkan rasa percaya diri pada istri, sehingga mentalnya cukup kuat dalam menghadapi proses kehamilan maupun persalinan. Memperhatikan secara detail kebutuhan istri dan menyembuhkan rasa percaya diri serta memberikan rasa aman (Nolan, 2003). Dukungan dapat berbentuk dukungan emosional, dukungan penghargaan, 
dukungan instrumental dan dukungan informative (Setiadi, 2008).

Berkaitan dengan bentuk dukungan suami, dilihat dari distribusi jawaban ibu terhadap kuesioner yang diberikan, bisa dikatakan bahwa suami dari ibu hamil sudah memberikan dukungan baik dukungan emosional, dukungan penghargaan, dukungan instrumental, dan dukungan informatif walaupun belum maksimal.

Dukungan suami sebagai faktor yang paling dominan berpengaruh terhadap perencanaan persalinan diperkuat dengan adanya hubungan antara paritas dengan dukungan suami dalam perencanaan persalinan dan adanya hubungan antara pendapatan dengan dukungan suami dalam perencanaan persalinan. Kaitan antara paritas dengan dukungan suami dalam perencanaan persalinan ini bisa dijelaskan dari sisi psikologis, dimana biasanya psikologis ibu yang pernah melahirkan lebih stabil dibanding dengan ibu yang belum pernah melahirkan. Ketidakstabilan psikologis ibu akan berdampak pada kesehatan ibu maupun bayi yang dikandungnya oleh sebab itu dukungan suami sangat diperlukan. Dukungan psikologis adalah suatu sikap yang memberikan dorongan dan penghargaan moril kepada ibu selama masa kehamilannya, misalnya suami sangat membantu ketenangan jiwa isterinya, suami mendambakan bayi dalam kandungan istri, suami menunjukkan kebahagiaan pada kehamilan, suami tidak menyakiti istri, suami menghibur atau menenangkan ketika ada masalah yang dihadapi isteri, suami berdoa untuk kesehatan atau keselamatan istri dan anaknya (Yanuasti, 2001).

Berkaitan dengan hubungan antara pendapatan dengan dukungan suami, dapat diketahui bahwa 75\%-100\% pendapatan pada masyarakat kita, kebanyakan dipergunakan untuk membiayai keperluan hidupnya. Sehingga banyak keluarga yang setiap bulan bersaldo rendah, tidak dapat memeriksakan ibu hamil ke tempat pelayanan kesehatan, karena tidak mempunyai kemampuan untuk membayar. Atas dasar faktor tersebut di atas, maka prioritas kegiatan GSI di tingkat keluarga dalam pemberdayaan suami tidak hanya terbatas pada kegiatan yang bersifat anjuran saja seperti yang selama ini akan tetapi akan bersifat holistik. Secara konkrit dapat dikemukakan bahwa pemberdayaan suami perlu dikaitkan dengan pemberdayaan ekonomi keluarga, sehingga kepala keluarga tidak mempunyai alasan untuk tidak memperhatikan kesehatan karena permasalahan keuangan (Yanuasti, 2001). 


\section{KESIMPULAN}

Berdasarkan hasil penelitian dapat ditarik beberapa kesimpulan antara lain : Sebanyak 62,2\% ibu hamil memiliki perilaku perencanaan persalinan untuk pencegahan komplikasi kehamilan yang kurang baik, dan sebanyak $37,8 \%$ ibu hamil memiliki perilaku perencanaan persalinan untuk pencegahan komplikasi kehamilan yang baik. Perilaku ibu hamil yang kurang baik dalam merencanakan persalinan untuk pencegahan komplikasi kehamilan ini, terutama meliputi adanya $57,80 \%$ ibu hamil yang tidak memiliki surat pernyataan kesediaan sarana transportasi, sebanyak $62,20 \%$ ibu hamil tidak memiliki surat pernyataan kesediaan menjadi pendonor darah.

Faktor-faktor yang berhubungan secara signifikan dengan perilaku ibu hamil dalam merencanakan persalinan untuk pencegahan komplikasi kehamilan adalah variabel pendapatan $(\mathrm{p}$-value $=0,002)$, paritas $(\mathrm{p}$ value $=0,011)$, pengetahuan $(\mathrm{p}$-value $=$ 0,000), sikap (p-value $=0,002)$, ketersediaan sarana dan prasarana $(\mathrm{p}$-value $=0,035)$, dukungan suami (p-value $=0,000)$, dan dukungan petugas kesehatan $(\mathrm{p}$-value $=$ 0,004). Sedangkan faktor-faktor yang tidak berhubungan secara signifikan dengan perilaku ibu hamil dalam merencanakan persalinan untuk pencegahan komplikasi kehamilan adalah variabel umur (p-value $=$ 0,310), pendidikan ( $\mathrm{p}$-value $=1,000)$, dan pekerjaan $(\mathrm{p}$-value $=0,399)$.

Faktor yang paling dominan berpengaruh terhadap perilaku ibu hamil dalam merencanakan persalinan untuk pencegahan komplikasi kehamilan adalah dukungan suami dalam perencanaan persalinan untuk pencegahan komplikasi kehamilan dengan nilai Odd Ratio 7,037. Selanjutnya faktor-faktor lain yang berpengaruh secara bersama-sama terhadap perilaku ibu hamil dalam merencanakan persalinan untuk pencegahan komplikasi kehamilan adalah: Sikap ibu hamil tentang perencanaan persalinan untuk pencegahan komplikasi kehamilan dengan nilai $O d d$ Ratio 6,637. Dukungan petugas kesehatan dalam perencanaan persalinan untuk pencegahan komplikasi kehamilan dengan nilai Odd Ratio 5,962. Pengetahuan tentang perencanaan persalinan untuk pencegahan komplikasi kehamilan dengan nilai $O d d$ Ratio 4,497.

Persentase suami yang kurang mendukung perencanaan persalinan untuk pencegahan komplikasi kehamilan adalah $36,7 \%$. Dimana dukungan yang kurang dari suami terutama adanya $31,1 \%$ suami yang tidak berperan mencarikan calon pendonor darah apabila dibutuhkan sewaktu-waktu. 
Persentase petugas yang kurang mendukung perencanaan persalinan untuk pencegahan komplikasi kehamilan adalah 31,1\%. Dimana dukungan yang kurang dari petugas terutama adanya $35 \%$ petugas kesehatan yang tidak memberi saran agar menyiapkan orang yang bersedia menjadi donor darah jika sewaktuwaktu diperlukan.

\section{SARAN}

Mengingat perilaku ibu hamil dalam merencanakan Persalinan untuk Pencegahan komplikasi masih rendah maka kami menyarankan kepada Dinas Kesehatan Kota Semarang untuk : a) Melakukan monitoring, evaluasi dan pembinaan kepada puskesmas secara berkelanjutan untuk meningkatkan kinerja puskesmas khususnya dalam hal pelaksanaan Program P4K; b) Melakukan koordinasi dengan Puskesmas dan Lintas Sektor, dalam rangka mengaktifkan desa /Kelurahan Siaga aktif sebagai wadah pemberdayaan masyarakat dalam bidang kesehatan khususnya dalam Program P4K, seperti dalam penyediaan sarana transportasi untuk melahirkan, juga membentuk forum penggalangan donor darah, bekerja sama dengan PMI Kota Semarang, dan melakukan surveilan terhadap masalah kesehatan khususnya masalah kesehatan ibu hamil; c) Melaksanakan pelatihan bagi tenaga kesehatan khususnya bidan untuk meningkatkan keahlian dalam bidang kesehatan khususnya program yang berkaitan dengan P4K; d) Meningkatkan jejaring dengan Lintas Sektor khususnya yang berkaitan dengan kesehatan misalnya dengan PKK, LPMK, Bapermas dalam rangka penyebarluasan informasi kesehatan khususnya yang berkaitan dengan P4K.

Saran bagi Puskesmas adalah: a) Melakukan minilokakarya secara berkala untuk mengevaluasi pelaksanaan program puskesmas dan masalah-masalah yang timbul di lapangan dengan tujuan agar bisa dengan cepat menyusun perencanaan dalam rangka pemecahan masalah terutama masalah yang berkaitan dengan kehamilan; b) Melakukan monitoring dan pengawasan terhadap kinerja tenaga kesehatan khususnya bidan yang berhubungan langsung dengan kesehatan ibu hamil; c) Membentuk pembinaan wilayah (Binwil) yang tenaganya berasal dari tenaga kesehatan di masing-masing desa/kelurahan, yang mana Binwil tersebut bertanggungjawab terhadap keberlangsungan dan kelancaran pelaksanaan Desa / kelurahan Siaga aktif; d) Memerintahkan kepada tenaga kesehatan untuk aktif dalam melakukan surveilan di lapangan dalam rangka penemuan dini masalah kesehatan; e) 
Memberlakukan sanksi terhadap tenaga kesehatan yang memiliki kinerja tidak baik.

Saran bagi bidan adalah : a) Melakukan pendekatan secara rutin kepada tokoh masyarakat, tokoh agama, agar suami selalu siaga apabila istrinya hamil; b) Memberikan konseling kepada suami secara rutin pada saat istrinya melakukan pemeriksaan kehamilan; c) Aktif melakukan kunjungan lapangan terutama kepada ibu hamil di masyarakat; d) Memberikan informasi yang berkaitan dengan P4K :tanda bahaya kehamilan dan persalinan, penyediaan transportasi ,menyiapkan pendonor darah , golongan darah yang harus diketahui oleh ibu hamil secara tuntas; e) Aktif mengikuti pertemuan-pertemuan yang dilaksanakan oleh Desa/Kelurahan, misalnya pertemuan Desa Siaga, pertemuan PKK, dan pertemuan LPMK ataupun pertemuan lainnya untuk memperoleh informasi-informasi yang dibutuhkan oleh masyarakat terutama yang berkaitan dengan masalah kehamilan.

Saran bagi masyarakat : a) Masyarakat harus aktif terhadap program perencanaan persalinan, khususnya berpartisipasi secara aktif meminjamkan alat transportasinya bila sewaktu-waktu ada yang membutuhkan; b)
Masyarakat harus aktif mengetahui jenis golongan darahnya, untuk mengantisipasi jika sewaktu-waktu darahnya diperlukan untuk penanganan kegawatdaruratan ibu dalam persalinan.

Berkaitan dengan pentingnya program P4K bagi ibu hamil dalam rangka menurunkan angka kematian ibu dan bayi dan berdasarkan hasil penelitian yang secara kuantitatif ini hanya mampu mengungkap faktor-faktor yang berhubungan dengan Perilaku Ibu hamil dalam Program P4K, maka kami menyarankan kepada peneliti selanjutnya untuk melakukan: penelitian secara kualitatif tentang pelaksanaan P4K ditinjau dari masyarakat itu sendiri, peran stake holder dalam $\mathrm{P} 4 \mathrm{~K}$, sejauh mana peran Dinas Kesehatan, Puskesmas, dan para bidan dalam P4K sehingga dengan demikian dari penelitian tersebut bisa digali secara mendalam akar permasalahannya, sehingga bisa ditemukan solusi yang tepat dalam mengatasi masalah tersebut. Penelitian secara kualitatif tentang upaya-upaya peningkatan pemberdayaan masyarakat dalam $\mathrm{P} 4 \mathrm{~K}$, serta penelitian secara kuantitatif tentang faktorfaktor yang berpengaruh terhadap kinerja bidan dalam $\mathrm{P} 4 \mathrm{~K}$. 


\section{KEPUSTAKAAN}

Dinkes Jateng. 2008. Profil Kesehatan Provinsi Jawa Tengah Tahun 2008. Dinas Kesehatan Jawa Tengah. Semarang. Dalam: http://www.dinkesjatengprov.go.id/doku men/profil/2008/index.htm.(diakses tanggal 5 Oktober 2011).

Depkes. 2010. Profil Indonesia Sehat 2009. Departemen Kesehatan RI. Jakarta. Dalam: http://www.depkes.go.id/downloads/PROFI L_KESEHATAN_INDONESIA_2010.pdf. (diakses pada tanggal 5 Oktober 2011).

Dinkes Jateng. 2011. Profil Kesehatan Provinsi Jawa Tengah Tahun 2011. Dinas Kesehatan Jawa Tengah. Semarang.

Depkes. 2009. Pedoman Program Perencanaan Persalinan dan Pencegahan dengan Stiker. Departemen Kesehatan RI. Jakarta.

Dinkes NTB. 2008. Pedoman Pelaksanaan Pemberdayaan Masyarakat Bidang Kesehatan Ibu dan Anak. Dinas Kesehatan Propinsi Nusa Tenggara Barat. NTB.

Lawrence W. Green \& Marshall W. Kreuter. 2000. Health Promotion Planning: an Educational and Environmental
Approach Second Edition. Mayfield Publishing Company. California.

Kholid, A. 2012. Promosi Kesehatan : Dengan Pendekatan Teori Perilaku, Media dan Aplikasinya. PT. Raja Grafindo Persada. Jakarta.

Siregar, S. 2012. Statistika Deskriptif untuk penelitian. Rajawali Press. Jakarta.

Dinkes Kota Semarang. 2012. Laporan Data Kematian Maternal kota Semarang Provinsi Jawa Tengah Tahun 2012. Dinas Kesehatan Kota Semarang. Kota Semarang.

Notoatmodjo, S. 2003. Pendidikan dan Perilaku Kesehatan. Rineka Cipta. Jakarta.

Notoatmodjo, S. 2010. Metodologi Penelitian kesehatan. Rineka Cipta. Jakarta.

Jalaluddin, R. 2012. Psikologi Komunikasi. PT. Remaja Rosdakarya. Bandung.

Ahmadi, A. 2002. Psikologi Sosial. Rineka Cipta. Jakarta.

Setiadi. 2008. Konsep Dan Proses Keperawatan Keluarga. Penerbit Ganbika. Yogyakarta.

Nolan, M. 2003. Kehamilan dan Melahirkan. EGC. Jakarta.

Yanuasti. 2001. Dukungan Sosial Suami Terhadap Pelayanan ANC. Nuha Medika. Yogyakarta. 